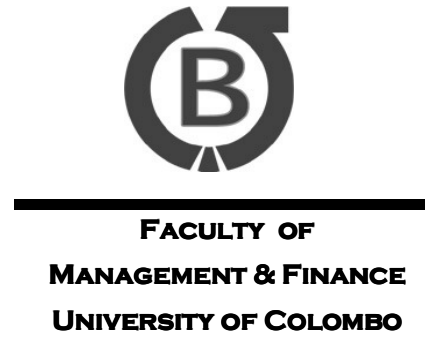

Colombo

Business

Journal

INTERNATIONAL JOURNAL OF

THEORY \& PRACTICE

Vol. 08, No. 02, December, 2017

\title{
Information Content of Insider Trading Volume: Evidence from Sri Lanka
}

\author{
K. L. U. D. Perera ${ }^{\text {， P. D. Nimal }}{ }^{\mathrm{a}}$ \\ ${ }^{a}$ Department of Finance, University of Sri Jayewardenepura, Sri Lanka
}

\begin{abstract}
This study examines whether high volume directors' trading is more informative than low volume directors' trading. It further examines the speed of adjustment of stock prices for the information content of high volume directors' trading of the listed companies in the Colombo Stock Exchange (CSE). This study analyses a sample of high rupee-volume and percentage-volume directors' purchases and sales reported to the CSE during September, 2004 to August, 2012 using the standard event study methodology. The findings on the high rupee-volume trading are consistent with the hypotheses that high rupee-volume directors' purchases (sales) are associated with positive (negative) abnormal returns. Although the abnormal returns of percentage-volume directors' sales are negative and significant, the high percentage-volume directors' purchases are not significant. The findings on the speed of adjustment of stock prices on these information are not conclusive. I.e., the abnormal returns of high rupee-volume directors' purchases are positive and significant on the event day and the abnormal returns of high rupee-volume and percentage-volume director's sales are negative and significant but have been reflected in the stock prices with a delay suggesting that the adjustment of stock prices for director's sales may not be quick in the CSE.
\end{abstract}

Keywords: Abnormal Returns, Information Asymmetry, Insider Trading, Market Efficiency, Trading Volume

1Corresponding Author:pdnimal@sjp.ac.lk

iD https://orcid.org/0000-0003-3743-4489

This work is licensed under a Creative Commons Attribution 4.0 International License. 


\section{Introduction}

The Efficient Market Hypothesis (EMH) (Fama, 1970) suggests that all public information is fully reflected in market prices of securities when the market is semi strong form efficient and high trading volume of insiders should not trigger any abnormal changes in that market. The high trading volume of insiders may not be necessarily related to new information disclosure. The stock markets often show sudden and large changes in prices and trading volumes which becomes difficult to attribute to any new information disclosure rather could be attributable to the trades done by insiders.

Information signalling hypothesis implies that insiders purchase (sell) securities when they are aware of good (bad) news that affect security prices to go up (down) (Louis, Sun, \& White, 2010). Additionally, the evidences suggest that the insiders tend to trade in large volumes when they are aware of more positive or negative information (Easley \& O'Hara, 1992). Thus, higher trading volume of insider purchases (sales) could be perceived as positive (negative) signals that contains positive (negative) information.

Easley and O'Hara (1992) and Bajo (2010) state that traders with unreported information would prefer to trade in large volumes. Glosten and Milgrom (1985) state that the trade imbalance arising in the market due to insiders' purchases or sales could force security prices to reflect the underlying information content of these trades. Consistent with these arguments, empirical studies on insider trading finds that insider purchases (sales) are associated with positive (negative) abnormal returns in the US market (Lakonishok \& Lee, 2001), in the Hong Kong market (Cheung, Wong, \& Wu, 2000), in the UK market (Aktas, De Bodt, De Smedt, \& Riachi, 2007) and in the New Zealand market (Etebari, Tourani-Rad, \& Gilbert, 2004). Comiskey, Walkling, and Weeks, (1987) find a significant and positive correlation between trading volume and the absolute value of price changes and Karpoff, $(1986,1987)$ confirms this positive relationship both in equity and futures markets. Moreover, Wong (2002) finds that there are abnormally significant volume fluctuations in the pre event windows for good and bad news in the Hong Kong market and attributes the same for the trades done by insiders.

In addition, Frankel and $\mathrm{Li}$ (2004) argue that if a significant proportion of the securities market turnover of a security within a particular day includes insider trades and insiders have a wide ownership on that security, outsiders take into account these trades as more informative. Bajo and Petracci (2006) confirm this 
argument and find a positive relationship between the change of holding of insiders and the securities market movement. Seyhun (1986) also confirms a positive relationship between the proportion of the firm traded and the insider's abnormal returns.

However, evidence on the speed of market reaction to insider trading information is not consistent. The US market has shown a delayed reaction in the long run for insider trades (Seyhun, 1986; Lakonishok \& Lee, 2001). The Italian market (Barucci, Bianchi, \& Manconi, 2006), and the Hong Kong market (Cheung et al., 2000) have reacted in the short run for the information content of insider trades. Furthermore, Bajo (2010) finds that the market immediately reacts to the information content of abnormal trading volumes. Bajo and Petracci (2006) find that the market react for the information content of change in holding percentages of insiders with a delay.

In the Colombo Stock Exchange, Perera and Nimal (2015) find supportive evidence only under Risk Adjusted Return (RAR) model for the hypothesis that abnormal returns for directors' purchases are positive. The findings on directors' purchases under Market Adjusted Return (MAR) model are not significant and contrary to the hypothesis that the abnormal returns for directors' sales are positive under both MAR and RAR models. Further, Pathirawasam (2011) concludes that stock returns are positively related to the contemporary changes in trading volume and past trading volume change is negatively related to stock returns in the CSE. However, the CSE does not provide consistent evidence on the market efficiency. Dissabandara (2001) finds that the CSE reacts with a delay for an increase or decrease in dividends; Gunathilake and Kongahawatte (2011) identify that the CSE reacts to the information content of stock splits immediately on the event day; Edirisinghe and Nimal (2015) conclude that price adjustment to the right issues is not efficient in the CSE.

However, it is hard to find any published study that analyses the information content of abnormal trading volumes of insiders in the CSE. Thus, studying the information content of abnormal trading volumes of insiders and the market reaction to such information would be an interesting study to be carried out in the Sri Lankan capital market.

Furthermore, studies of this nature have been extensively carried out in both developed and emerging markets but not in frontier markets like Sri Lanka. Sri 
Lanka could be considered as a frontier market given its recent economic growth and development of the stock market. It is hard to find any published studies on the information content of insider's trading-volume and the speed of the adjustment of stock prices for insider's trading-volume in the CSE. Hence, it would be important for both policymakers and investors to know the information content of large volume insider's trading and the speed of their reflection in the stock prices in the CSE.

In the literature on insider trading of top officers, directors and large shareholders of firms are considered as insiders. However, with the disclosure requirements of the CSE, the quoted public companies in Sri Lanka are required to report only the insider trades of directors. Therefore, this study analyses only the disclosed purchases and sales of directors of the quoted public companies in the CSE.

Accordingly, this study first analyses whether the high rupee-volume director's purchases (sales) are more informative than the low rupee-volume director's purchases (sales) and whether the high percentage-volume director's purchases (sales) are more informative than the low percentage-volume director's purchases (sales). Secondly, this study examines the speed of the adjustment of security prices to reflect the information content of high trading volumes of directors' of listed companies in the CSE.

The analysis of the study is done using data of the CSE from September, 2004 to August, 2012 due to the non-availability of organised data from 2012 onwards which may not have affected the results because there have been no turbulent events in the recent past in the CSE that could have drastically changed the results. However, it would have been better if recent data is included for the analysis.

\section{Research Questions and Hypotheses}

The research questions and the hypotheses of this study are as follows.

RQ1: Are large volumes of director's trading transactions more informative?

$\mathrm{H}_{1}$ : Positive abnormal returns of high rupee-volume director's purchases are greater than the positive abnormal returns of low rupee-volume director's purchases.

$\mathrm{H}_{2}$ : Negative abnormal returns of high rupee-volume director's sales are greater than the negative abnormal returns of low rupee-volume director's sales. 
$\mathrm{H}_{3}$ : Positive abnormal returns of high percentage-volume director's purchases are greater than the positive abnormal returns of low percentage-volume director's purchases.

$\mathrm{H}_{4}$ : Negative abnormal returns of high percentage-volume director's sales are greater than the negative abnormal returns of low percentage-volume director's sales.

RQ2: Does the market adjust security prices to reflect information content of directors' trading volume immediately?

$\mathrm{H}_{5}$ : The market adjusts security prices rapidly to reflect information content of directors' rupee-volume and percentage-volume trading.

\section{Research Design}

Depending on the availability of data, the sample period of this study is from September, 2004 to August, 2012. The sample consists of directors' purchases events from 156 companies and directors' sales events from 131 companies. There are 2201 directors' purchases events and 941 directors' sales events in the sample. The study develops two sub samples based on rupee-volume and percentage-volume director's purchases and sales over the days' market turnover of that security. The sub samples include the highest 10 per cent and the lowest 10 per cent of directors' purchases (sales) ranked according to rupee-volume and percentage-volume directors' purchases (sales). Accordingly, high/low rupee-volume and percentagevolume directors' purchases sample include 220 directors' purchase events and sales sample include 94 directors' sales events. Further, directors' purchases (sales) carried out under Employee Share Option Schemes (ESOPs), Trust Deeds, Share Warrants and directors' trades of non-voting ordinary securities have been excluded from the sample and certain directors' trading events have been excluded due to thin trading problem as well.

If efficient, the market is expected to react to the high volume of directors' trades on the transaction day. Lakonishok and Lee (2001) conclude that a larger abnormal return is reported around the trading period of insider trades than in the reporting period. Hence, this study also considers directors' trading date as the event day $(t=0)$ instead of the reporting date to the CSE.

Due to the high volume of events considered, it is not practical to set event windows for each security and for each event separately. Therefore, this study adopts a fixed event window for both directors' purchases and sales events and for 
all the companies. The studies on analysing insider trading have adopted different event windows such as -21 to +21 days (Bajo \& Petracci, 2006) and -20 to +20 (Barucci et al., 2006). The underlying assumption of this event window length is that the insider trades would be reflected in security prices within a shorter time horizon. Therefore, it is decided that a shorter event window would be appropriate to measure the impact of abnormal trading volume of directors' in the CSE as well. Accordingly, this study uses a fixed event window of -20 to +20 days. Further, following Perera and Nimal (2015), a fixed estimation window of 41 days before the pre event window is considered to estimate the beta of securities in order to measure the risk adjusted rate of return of securities of each event.

Since the degree of information asymmetry between insiders and outsiders cannot be measured directly, following Seyhun (1986) and Rozeff and Zaman (1988), this study also uses the profitability of directors' trades as the proxy to measure the impact of insider trading. The profitability is measured following the event study methodology of MacKinlay (1997) and Brown and Warner (1985). According to MacKinlay (1997), there are several choices for modeling the abnormal returns. This study adopts only the Risk Adjusted Return (RAR) Model which is more appropriate and widely used than market adjusted and mean adjusted models. The daily abnormal return of the event window is calculated using RAR model as given below.

Abnormal return under the RAR Model

$A R_{i t}=R_{i t}-\left[R_{f t}+\beta_{i}\left(R_{m t}-R_{f t}\right)\right]$

where,

$A R_{i t}$ - Abnormal return for security $i$ at day $t$

$R_{i t}-$ Actual return for security $i$ at day $t$

$R_{f t}$ - Risk free rate of return i.e. 91 days Treasury bill rate at day $t$

$R_{m t}$ - Actual return for the market portfolio at day $t$

$\beta_{i}$ - Systematic risk of security $i$

Following Nimal (2006) the actual returns of securities are calculated after adjusting for capital gains, dividends, bonus issues, stock splits and right issues assuming that all the forms of returns are reinvested in the same security. Further, beta coefficients of securities for each event are estimated using the market model given below. 
$R_{i t}=a_{i}+\beta_{i}\left(R_{m t}\right)+\varepsilon_{i t}$

where $t$ goes from -61 to -21

Then, the Average Abnormal Return (AAR) and Cumulative Average Abnormal Return (CAAR) for each day of the event window are calculated using the equations given below.

$$
A A R_{t}=\frac{1}{\mathrm{~N}} \sum_{i=1}^{\mathrm{n}} A R_{i t}
$$

where,

$\mathrm{AAR}_{t}-$ Average Abnormal Return at day $t$

$\mathrm{N}$ - Total number of events

$\operatorname{CAAR}_{\left(t_{1}, t_{2}\right)}=\sum_{\mathrm{t}=t_{1}}^{t_{2}} A A R_{t}$

where,

$\operatorname{CAAR}_{\left(t_{1}, t_{2}\right)}$ - Cumulative Average Abnormal Return from $t_{1}$ to $t_{2}$

In this study, the excess AAR/CAAR are calculated as the difference between the AAR/CAAR of highest $10 \%$ and the lowest $10 \%$ of directors' trades sub samples ranked on the rupee and percentage-volume of directors' trading. The $t$ statistics of excess AAR/CAAR are calculated following MacKinlay (1997) and Brown and Warner (1985) and the significance of these statistics is tested using the standard $t$-test.

The $t$-statistic for AAR for any day $t$;

$t$ - stat $=\frac{{\text { Excess } A A R_{t}}_{\sigma\left(E_{1} \operatorname{coss} A A R_{t}\right)}}{\sigma}$

where,

$\sigma\left(\right.$ Excess $\left.A A R_{t}\right)-$ Standard deviation of the Average Abnormal Returns across time

The $t$-statistic for CAAR for any day $t$;

$t$-stat $=\frac{\operatorname{Excess}^{2} \operatorname{CAAR}_{\left(t_{1}, t_{2}\right)}}{\left[\sigma^{2}\left(t_{1}, t_{2}\right)\right]^{1 / 2}}$

where

$\sigma^{2}\left(t_{1}, t_{2}\right)=\sigma^{2} L\left(\right.$ Excess $\left.A A R_{t}\right)$

$\sigma^{2}$ (Excess $\left.A A R_{t}\right)$ - Variance of the Average Abnormal Returns across time

$L=t_{1}-t_{2}+1$ (i.e. the horizon length of the event time) 


\section{Findings}

Following the methodology explained in the previous section, excess AAR, excess CAAR and their respective $t$-statistics for each day of the event period for directors' rupee-volume and percentage-volume purchases and sales are presented in Appendices 1 and 2 respectively and they are graphically depicted in Figures 1,2, 3 , and 4 respectively. These graphs display whether the market has shown an early reaction, immediate reaction or delayed reaction for the information content of directors' purchases and sales. Further, excess CAAR for directors' purchases and sales under both sub samples over different event windows are presented in Tables 1 and 2 in order to identify how the directors' rupee-volume and percentage-volume trading information are reflected in market prices during the event period.

\section{Figure 1: Excess AAR \& CAAR of Rupee-Volume Purchases}

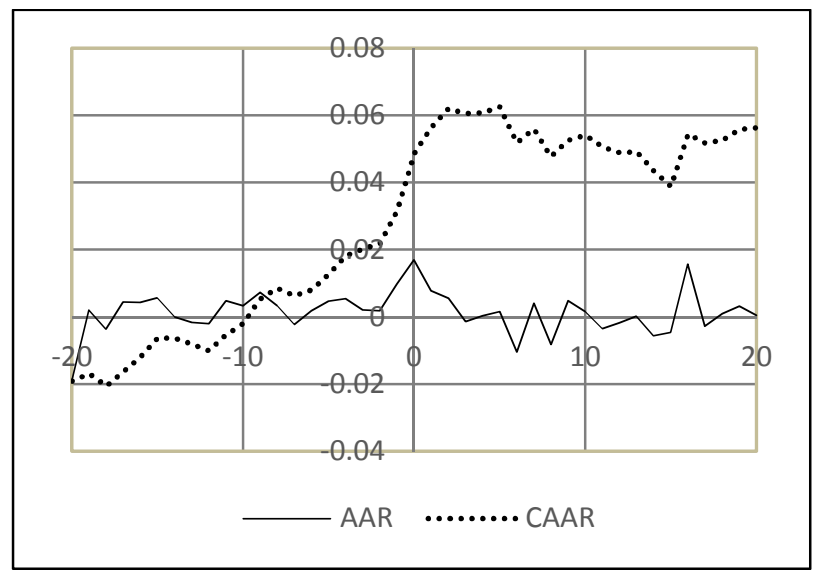

Figure 2: Excess AAR \& CAAR of Rupee-Volume Sales

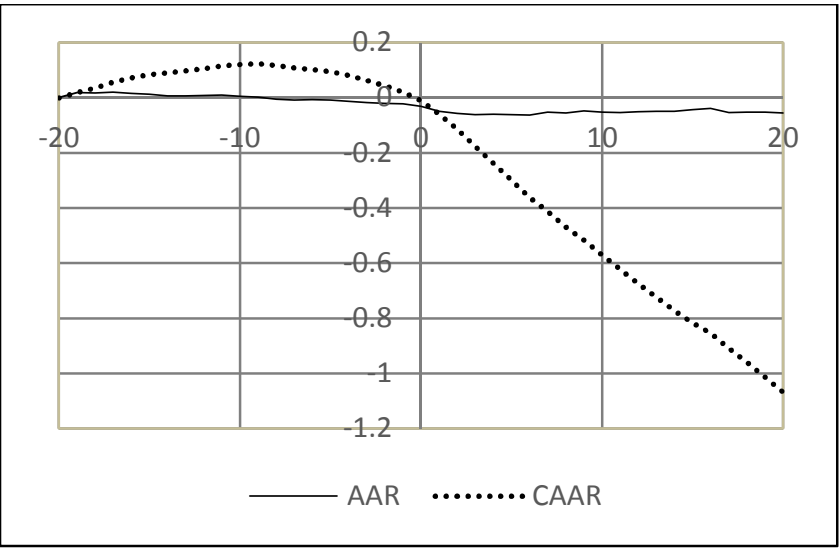


Figure 3: Excess AAR \& CAAR of Percentage-Volume Purchases

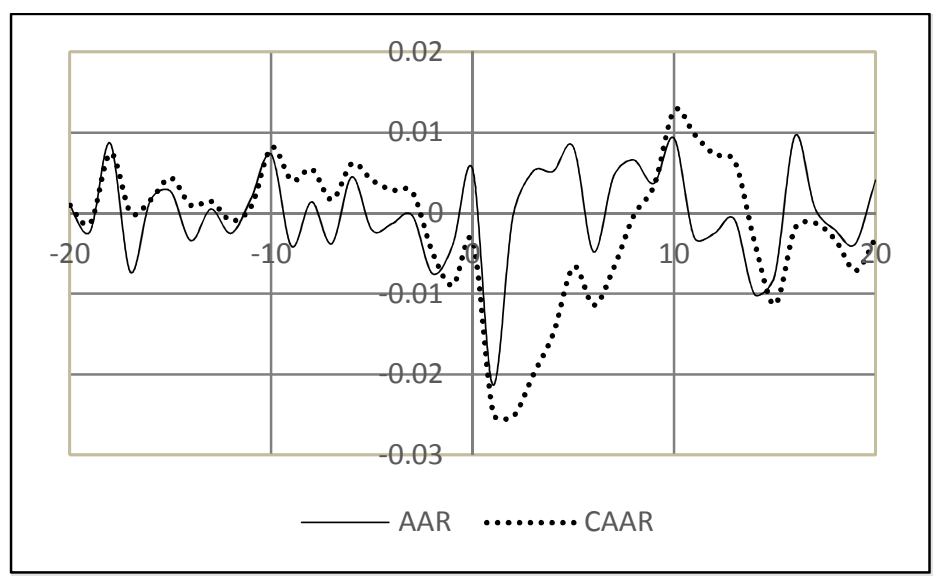

Figure 4: Excess AAR \& CAAR of Percentage-Volume Sales

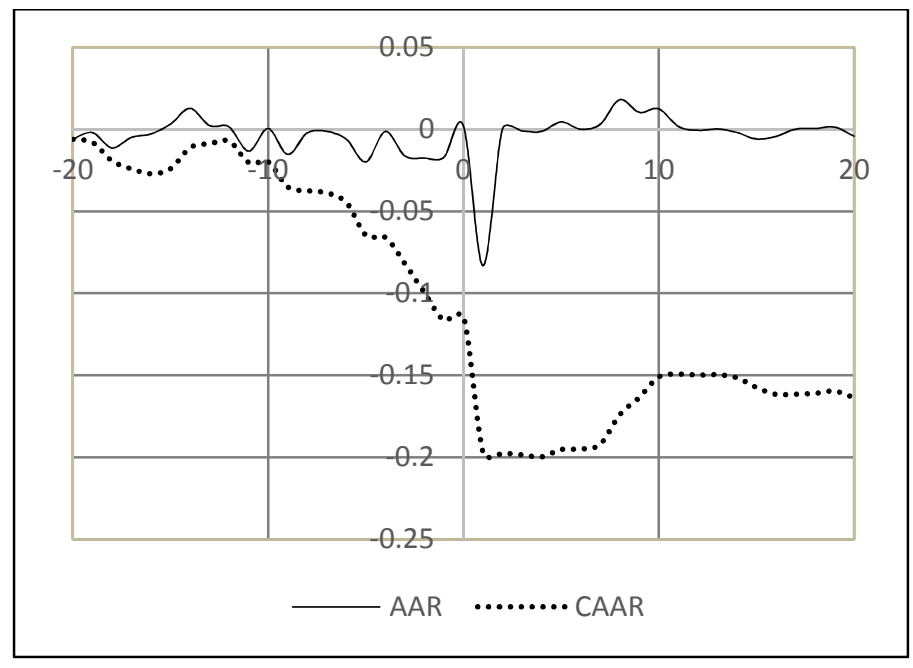

The findings suggest that rupee-volume excess AAR and excess CAAR (Appendix 1) of directors' purchases/sales are positive/negative and significant as hypothesised. Also, the percentage-volume excess AAR and excess CAAR (Appendix 2) of directors' sales are negative and significant as hypothesised. However, the percentage-volume excess AAR and excess CAAR (Appendix 2) of directors' purchases are not positive thus not consistent with the hypothesis. These findings are consistent with hypotheses 1,2 and 4 (this is clearly demonstrated in Figures 1, 2 and 4) and not consistent with hypothesis 3 only (as seen in Figure 3) suggesting that the volume of director's share trading seems informative in the CSE. 
However, as far as the speed of the adjustment of prices for information content of directors' trading volume is concerned, there are no conclusive evidences to say that the market is efficient. Rather it seems that there is a delayed reaction to the information content of share trading volume of directors. I.e., the excess AAR of rupee-volume directors' purchases are positive and significant on the event day but the excess CAAR is positive and significant on the second and third day after the event day. The excess AAR of rupee-volume directors' sales is negative and significant from day 3 to 6 after the event day and the excess CAAR of rupeevolume directors' sales is negative and significant from day 5 to day 20 after the event day (Appendix 1). Also the excess AAR of percentage-volume directors' sales is negative and significant on the first day after the event day and the excess CAAR of percentage-volume directors' sales is negative and significant from day 1 to 9 after the event day (Appendix 2). When both the Appendixes 1 and 2 are observed there is no evidence of significant excess AAR or excess CAAR before the event day. However, Figure 1 and Figure 4 show some kind of early response before the event day though not statistically significant. The findings of Figure 4 is further supported in Table 2 as the excess CAAR of percentage-volume directors' sales is significant and negative from day -10 to day -1 of the event period which is an evidence of early response to the information content of the directors' sales. Therefore, evidences on the market efficiency are not conclusive.

Table 1: Excess CAAR for Different Windows of Directors' Rupee-Volume Trading Sub Sample

\begin{tabular}{|c|c|c|c|c|c|c|c|}
\hline \multirow[b]{2}{*}{ Event Window } & \multirow[b]{2}{*}{$\mathbf{L}$} & \multicolumn{3}{|c|}{ Purchases } & \multicolumn{3}{|c|}{ Sales } \\
\hline & & CAAR & $t$-stat & $\begin{array}{l}(+) \\
\text { Returns \% }\end{array}$ & CAAR & $t$-stat & $\begin{array}{l}(+) \\
\text { Returns \% }\end{array}$ \\
\hline $\mathrm{W} 1=(-20,-1)$ & 20 & 0.0317 & 1.13 & $45.00 \%$ & 0.0214 & 0.17 & $100.00 \%$ \\
\hline $\mathrm{W} 2=(-10,-1)$ & 10 & 0.0370 & 1.86 & $90.00 \%$ & -0.0942 & -1.03 & $100.00 \%$ \\
\hline $\mathrm{W} 3=(-1,0)$ & 2 & 0.0267 & $3.00 *$ & $100.00 \%$ & -0.0537 & -1.32 & $50.00 \%$ \\
\hline $\mathrm{W} 4=(0,+1)$ & 2 & 0.0248 & $2.79 *$ & $100.00 \%$ & -0.0804 & $-1.97 *$ & $0.00 \%$ \\
\hline W $5=(-1,+1)$ & 3 & 0.0345 & $3.17 *$ & $100.00 \%$ & -0.1023 & $-2.05^{*}$ & $66.67 \%$ \\
\hline $\mathrm{W} 6=(+1,+10)$ & 10 & 0.0055 & 0.27 & $100.00 \%$ & -0.5593 & $-6.14^{*}$ & $0.00 \%$ \\
\hline $\mathrm{W} 7=(+1,+20)$ & 20 & 0.0076 & 0.27 & $100.00 \%$ & -1.0589 & $-8.21 *$ & $0.00 \%$ \\
\hline $\mathrm{W} 8=(-20,+20)$ & 41 & 0.0563 & 1.40 & $73.17 \%$ & -1.0693 & $-5.79 *$ & $48.78 \%$ \\
\hline
\end{tabular}

Note: This table summarizes excess CAAR for rupee-volume directors' purchases and sales for different window periods, respective $t$-statistics and percentage of the number of days excess CAAR has been positive during the respective event window period. The samples consist of highest $10 \%$ and lowest $10 \%$ of directors' purchases and sales ranked according to the trading rupee-volume. Accordingly, high/ low rupee-volume directors' purchases sample includes 220 directors' purchases events and sales sample includes 94 directors' sales events. * indicates statistical significance of test statistics at 0.05 level. 
Table 2: Excess CAAR for Different Windows of Directors' PercentageVolume Trading Sub Sample

\begin{tabular}{|c|c|c|c|c|c|c|c|}
\hline \multirow[b]{2}{*}{ Event Window } & \multirow[b]{2}{*}{$\mathbf{L}$} & \multicolumn{3}{|c|}{ Purchases } & \multicolumn{3}{|c|}{ Sales } \\
\hline & & CAAR & $t$-stat & $\begin{array}{l}(+) \\
\text { Returns \% }\end{array}$ & CAAR & $t$-stat & $\begin{array}{l}(+) \\
\text { Returns \% }\end{array}$ \\
\hline $\mathrm{W} 1=(-20,-1)$ & $\begin{array}{l}2 \\
0 \\
1\end{array}$ & -0.0089 & -0.33 & $80.00 \%$ & -0.1166 & -1.73 & $0.00 \%$ \\
\hline $\mathrm{W} 2=(-10,-1)$ & 0 & -0.0098 & -0.51 & $80.00 \%$ & -0.0963 & $-2.02 *$ & $0.00 \%$ \\
\hline $\mathrm{W} 3=(-1,0)$ & 2 & 0.0014 & 0.17 & $0.00 \%$ & -0.0149 & -0.70 & $0.00 \%$ \\
\hline $\mathrm{W} 4=(0,+1)$ & 2 & -0.0159 & -1.86 & $0.00 \%$ & -0.0810 & $-3.81 *$ & $0.00 \%$ \\
\hline W $5=(-1,+1)$ & $\begin{array}{l}3 \\
1\end{array}$ & -0.0198 & -1.91 & $0.00 \%$ & -0.0980 & $-3.76^{*}$ & $0.00 \%$ \\
\hline W $6=(+1,+10)$ & $\begin{array}{l}0 \\
2\end{array}$ & 0.0163 & 0.86 & $20.00 \%$ & -0.0364 & -0.77 & $0.00 \%$ \\
\hline $\mathrm{W} 7=(+1,+20)$ & $\begin{array}{l}0 \\
4\end{array}$ & 0.0004 & 0.02 & $25.00 \%$ & -0.0493 & -0.73 & $0.00 \%$ \\
\hline $\mathrm{W} 8=(-20,+20)$ & 1 & -0.0030 & -0.08 & $51.22 \%$ & -0.1637 & -1.70 & $0.00 \%$ \\
\hline
\end{tabular}

Note: This table summarizes excess CAAR for high percentage-volume directors' purchases and sales for different window periods, respective $t$-statistics and percentage of the number of days excess CAAR has been positive during the respective event window period. The samples consist of highest $10 \%$ and lowest $10 \%$ of directors' purchases and sales ranked according to the trading percentage-volume. Accordingly, high/ low percentage-volume directors' purchases sample includes 220 directors' purchases events and sales sample includes 94 directors' sales events. * indicates statistical significance of test statistics at 0.05 level.

\section{Discussion}

It is important to ensure the validity and reliability of the findings by comparing and contrasting the findings with evidences of previous literature. Initially, the abnormal returns of the rupee-volume directors' trades are compared with the findings of the previous studies. Subsequently, the abnormal returns of the percentage-volume directors' trades are compared with the findings of the previous studies.

Empirical evidences on information content of insider trading volumes are hardly found in emerging markets. In early studies, Karpoff (1987) mentions that the trading volume is positively related to the magnitude of the price change in equity markets. Further, Karpoff (1987) states that analysing the joint relationship between price changes and trading volume is important to study whether the volume has an information content that would create a price pressure in the securities market. This is consistent with the hypothesis that informed traders' trade aggressively when they have private information (Easley \& O'Hara, 1992; Suominen, 2001). In this regard, Seyhun (1986) finds that insiders (i.e. officers, 
directors, officer-directors, chairmen of the boards of directors, and large shareholders) can distinguish the differences in the quality of the information and therefore are willing to trade in large volumes when they have more valuable information.

For the Italian market, Bajo (2010) computes abnormal returns using both market model and market and risk adjusted model in an event study for a 16 day event window. The evidence of that study reports positive and strong significant abnormal returns on $(-2,+3)$ days around the abnormal trading volume events under market adjusted model and on $(-1,+2)$ days around the abnormal trading volume events under market and risk adjusted model. This evidence further supports the hypothesis that abnormal trading volumes are positively related with abnormal security returns in the Italian market. For the Hong Kong market, Wong (2002) finds that there are abnormally significant volume fluctuations in the pre event windows around day -15 for good (bad) news related to China affiliated stocks. These abnormal trading volumes reported are attributed for the trading by insiders using inside information.

As Glosten and Milgrom (1985) argue, this could be due to the trade imbalances in the market that would force prices to change to its full value. Heinkel and Kraus (1987) identify that insider purchases with high volume fractions reported positive abnormal returns and insider sales with high volume fractions reported negative abnormal returns on the event day but both are significant only marginally. Further, they mention that insider trading events occurring during a week with a low volume fraction reported insignificant CAARs in both pre and post event periods whereas insider trading during periods of high volume fraction was preceded by price increases, which might be due to the arrival of new information about the stock. Seyhun (1986) suggests that the proportion of the firm traded is positively related to insider's abnormal returns and significant at 1 per cent level. Bajo and Petracci (2006) also confirm that there is a positive relationship between the change of holding of the insiders and the sign of the market movement.

The findings of this study are also consistent with these findings that high volume directors' purchases and sales are associated with abnormal returns in the CSE and the speed of the adjustment of prices for these information has not been consistent in the CSE. 


\section{Conclusion}

In conclusion, the evidence implies that high trading volumes of directors' purchases and sales are informative and the average abnormal return of directors' trading volume is positive for directors' purchases and negative for directors' sales in the CSE. This could be due to the trade imbalances arising in the market ultimately forcing the security prices to reflect the new information. Similar to the findings of other studies, as far as the speed of reflection of the information content of directors' trading volume in the share price is concerned, there is no consistency which cast doubts on the efficiency of the CSE.

Finally, it is suggested to conduct a further study to analyze whether the information content of directors' trading volume could be captured more precisely in the long term by considering either weekly or monthly returns and to analyze whether an optimal trading strategy could be developed by following the aggregate directors' trading volume patterns to predict the future movement of the market and the future movement of individual security returns.

\section{References}

Aktas, N., De Bodt, E., De Smedt, J., \& Riachi, I. (2007). Legal insider trading and stock market reaction: Evidence from the Netherlands. Retrieved from http://www.uclouvain.be/cps/ucl/doc/core/documents/COREDP200767

Bajo, E. (2010). The information content of abnormal trading volume. Journal of Business Finance and Accounting, 37(7-8), 950-978.

Bajo, E., \& Petracci, B. (2006). Do what insiders do: Abnormal performance after the release of insider's relevant transactions. Studies in Economics and Finance, 23(2), 94-118.

Barucci, E., Bianchi, C., \& Manconi, A. (2006). Internal dealing regulation and insiders' trades in the Italian financial market. European Journal of Law and Economics, 22(2), 107-119.

Brown, S. J., \& Warner, J. B. (1985). Using daily stock returns: The case of event studies. Journal of Financial Economics, 14(1), 3-31.

Cheung, Y. L., Wong, M., \& Wu, L. (2000). Insider trading in the Hong Kong stock market. Asia-Pacific Financial Markets, 7(3), 275-288.

Comiskey, E., Walkling, R., \& Weeks, M. (1987). Dispersion of Expectations and trading volume. Journal of Business Finance \& Accounting, 14(2), 229-239. 
Dissabandara, D. B. P. H. (2001). Dividend signaling, market response to dividend change and capital market efficiency: An empirical analysis. Proceedings of the Annual Research Sessions 2000/2001, Faculty of Management Studies and Commerce, University of Sri Jayewardenepura, Sri Lanka.

Easley, D., \& O'Hara, M. (1992). Adverse Selection and large trade volume: The implications for market efficiency. The Journal of Financial and Quantitative Analysis, 27(2), 185-208.

Edirisinghe, U. C., \& Nimal, P. D. (2015). Stock price reaction to announcement of right issues and debenture issues: Evidence from Colombo Stock Exchange. International Journal of Business and Social Research, 5(2), 67-77.

Etebari, A., Tourani-Rad, A., \& Gilbert, A. (2004). Disclosure regulation and the profitability of insider trading: Evidence from New Zealand. Pacific-Basin Finance Journal, 12(5), 479-502.

Fama, E. F. (1970). Efficient capital markets: A review of theory and empirical work. The Journal of Finance, 25(5), 383-417.

Frankel, R., \& Li, X. (2004). Characteristics of a firm's information environment and the information asymmetry between insiders and outsiders. Journal of Accounting and Economics, 37(2), 229-259.

Glosten, L., \& Milgrom, P. R. (1985). Bid, ask, and transaction prices in a specialist market with heterogeneously informed agents. Journal of Financial Economics, 14(1), 71-100.

Gunathilake, C., \& Kongahawatte, S. (2011). Stock splits in Sri Lanka: Valuation effects and market liquidity. Proceedings of the Eighth International Conference on Business Management, Colombo, Sri Lanka.

Heinkel, R., \& Kraus, A. (1987). The effect of insider trading on average rates of return. The Canadian Journal of Economics, 20(3), 588-611.

Karpoff, J. M. (1986). A theory of trading volume. The Journal of Finance, 41(5), 1069-1088.

Karpoff, J. M. (1987). The relation between price changes and trading volume: A survey. The Journal of Financial and Quantitative Analysis, 22(1), 109-126.

Lakonishok, J., \& Lee, I. (2001). Are insider trades informative? The Review of Financial Studies, 14(1), 79-111.

Louis, H., Sun, A. X., \& White, H. (2010). Insider trading after repurchase tender offer announcements: Timing versus informed trading. Financial Management, 39(1), 301-322.

MacKinlay, A. C. (1997). Event studies in Economics and Finance. Journal of Economic Literature, 35(1), 13-39. 
Nimal, P. D. (2006). Empirical analysis of the Capital Asset Pricing Model, (Unpublished Doctoral Thesis). University of Shiga, Japan.

Pathirawasam, C. (2011). The relationship between trading volume and stock returns. Journal of Competitiveness, 3, 41-49.

Perera, K. L. U. D., \& Nimal, P. D. (2015). Information content of insider trading: Evidence from Colombo Stock Exchange. Asian Journal of Management Research, 5(4), 570-582.

Rozeff, M. S., \& Zaman, M. A. (1988). Market efficiency and insider trading: New Evidence. Journal of Business, 61(1), 25-44.

Seyhun, H. N. (1986). Insiders' profits, costs of trading, and market efficiency. Journal of Financial Economics, 16(2), 189-212.

Suominen, M. (2001). Trading volume and information revelation in stock markets. The Journal of Financial and Quantitative Analysis, 36(4), 545-565.

Wong, E. (2002). Investigation of market efficiency: An event study of insider trading in the stock exchange of Hong Kong, (Unpublished manuscript). Stanford University, US.

\section{Appendix 1: Excess AAR and Excess CAAR for Directors' Rupee-Volume} Trading Sub Sample

\begin{tabular}{|c|c|c|c|c|c|c|c|c|}
\hline \multirow[b]{2}{*}{ Day } & \multicolumn{4}{|c|}{ Purchases } & \multicolumn{4}{|c|}{ Sales } \\
\hline & $\begin{array}{l}\text { Excess } \\
\text { AAR }\end{array}$ & $t$-stat & $\begin{array}{l}\text { Excess } \\
\text { CAAR R }\end{array}$ & $t$-stat & $\begin{array}{c}\text { Excess } \\
\text { AAR } \\
\end{array}$ & $t$-stat & $\begin{array}{l}\text { Excess } \\
\text { CAAR } \\
\end{array}$ & $t$-stat \\
\hline-20 & -0.0191 & $-3.0302 *$ & -0.0191 & $-3.0302 *$ & 0.0000 & 0.0000 & 0.0000 & 0.0000 \\
\hline-19 & 0.0021 & 0.3374 & -0.0169 & -1.9041 & 0.0191 & 0.6610 & 0.0191 & 0.4674 \\
\hline-18 & -0.0037 & -0.5857 & -0.0206 & -1.8928 & 0.0169 & 0.5874 & 0.0360 & 0.7208 \\
\hline-17 & 0.0044 & 0.6985 & -0.0162 & -1.2900 & 0.0206 & 0.7152 & 0.0566 & 0.9818 \\
\hline-16 & 0.0043 & 0.6806 & -0.0119 & -0.8495 & 0.0162 & 0.5628 & 0.0728 & 1.1298 \\
\hline-15 & 0.0057 & 0.9042 & -0.0063 & -0.4063 & 0.0119 & 0.4143 & 0.0848 & 1.2006 \\
\hline-14 & -0.0001 & -0.0121 & -0.0063 & -0.3807 & 0.0063 & 0.2171 & 0.0910 & 1.1936 \\
\hline-13 & -0.0017 & -0.2755 & -0.0081 & -0.4535 & 0.0063 & 0.2197 & 0.0974 & 1.1942 \\
\hline-12 & -0.0021 & -0.3308 & -0.0101 & -0.5379 & 0.0081 & 0.2798 & 0.1054 & 1.2192 \\
\hline-11 & 0.0048 & 0.7680 & -0.0053 & -0.2674 & 0.0101 & 0.3520 & 0.1156 & 1.2679 \\
\hline-10 & 0.0033 & 0.5204 & -0.0020 & -0.0981 & 0.0053 & 0.1845 & 0.1209 & 1.2645 \\
\hline-9 & 0.0073 & 1.1665 & 0.0053 & 0.2429 & 0.0020 & 0.0709 & 0.1230 & 1.2312 \\
\hline-8 & 0.0033 & 0.5286 & 0.0086 & 0.3799 & -0.0053 & -0.1835 & 0.1177 & 1.1320 \\
\hline-7 & -0.0023 & -0.3696 & 0.0063 & 0.2673 & -0.0086 & -0.2988 & 0.1090 & 1.0109 \\
\hline-6 & 0.0018 & 0.2911 & 0.0081 & 0.3334 & -0.0063 & -0.2182 & 0.1028 & 0.9203 \\
\hline-5 & 0.0047 & 0.7468 & 0.0128 & 0.5095 & -0.0081 & -0.2817 & 0.0946 & 0.8207 \\
\hline
\end{tabular}




\begin{tabular}{|c|c|c|c|c|c|c|c|c|}
\hline \multirow[b]{2}{*}{ Day } & \multicolumn{4}{|c|}{ Purchases } & \multicolumn{4}{|c|}{ Sales } \\
\hline & $\begin{array}{c}\text { Excess } \\
\text { AAR }\end{array}$ & $t$-stat & $\begin{array}{l}\text { Excess } \\
\text { CAAR }\end{array}$ & $t$-stat & $\begin{array}{c}\text { Excess } \\
\text { AAR }\end{array}$ & $t$-stat & $\begin{array}{l}\text { Excess } \\
\text { CAAR } \\
\end{array}$ & $t$-stat \\
\hline-4 & 0.0054 & 0.8588 & 0.0182 & 0.7026 & -0.0128 & -0.4446 & 0.0818 & 0.6883 \\
\hline-3 & 0.0020 & 0.3203 & 0.0202 & 0.7583 & -0.0182 & -0.6320 & 0.0636 & 0.5200 \\
\hline-2 & 0.0018 & 0.2783 & 0.0220 & 0.8019 & -0.0202 & -0.7018 & 0.0434 & 0.3451 \\
\hline-1 & 0.0097 & 1.5460 & 0.0317 & 1.1273 & -0.0220 & -0.7625 & 0.0214 & 0.1658 \\
\hline 0 & 0.0170 & $2.6953 *$ & 0.0487 & 1.6883 & -0.0317 & -1.0998 & -0.0103 & -0.0781 \\
\hline 1 & 0.0078 & 1.2458 & 0.0565 & 1.9151 & -0.0487 & -1.6878 & -0.0590 & -0.4362 \\
\hline 2 & 0.0055 & 0.8738 & 0.0620 & $2.0552^{*}$ & -0.0565 & -1.9595 & -0.1155 & -0.8352 \\
\hline 3 & -0.0014 & -0.2285 & 0.0606 & $1.9653^{*}$ & -0.0620 & $-2.1501 *$ & -0.1775 & -1.2565 \\
\hline 4 & 0.0003 & 0.0470 & 0.0608 & 1.9350 & -0.0606 & $-2.1003 *$ & -0.2380 & -1.6512 \\
\hline 5 & 0.0016 & 0.2572 & 0.0625 & 1.9479 & -0.0608 & $-2.1105^{*}$ & -0.2989 & $-2.0330 *$ \\
\hline 6 & -0.0105 & -1.6774 & 0.0519 & 1.5886 & -0.0625 & $-2.1666^{*}$ & -0.3613 & $-2.4120 *$ \\
\hline 7 & 0.0041 & 0.6561 & 0.0560 & 1.6840 & -0.0519 & -1.8007 & -0.4132 & $-2.7088^{*}$ \\
\hline 8 & -0.0083 & -1.3144 & 0.0478 & 1.4106 & -0.0560 & -1.9438 & -0.4693 & $-3.0227 *$ \\
\hline 9 & 0.0048 & 0.7683 & 0.0526 & 1.5272 & -0.0478 & -1.6571 & -0.5170 & $-3.2744 *$ \\
\hline 10 & 0.0015 & 0.2410 & 0.0541 & 1.5456 & -0.0526 & -1.8247 & -0.5697 & $-3.5489 *$ \\
\hline 11 & -0.0035 & -0.5515 & 0.0507 & 1.4238 & -0.0541 & -1.8773 & -0.6238 & $-3.8249 *$ \\
\hline 12 & -0.0018 & -0.2794 & 0.0489 & 1.3534 & -0.0507 & -1.7570 & -0.6744 & $-4.0723 *$ \\
\hline 13 & 0.0002 & 0.0385 & 0.0491 & 1.3400 & -0.0489 & -1.6960 & -0.7233 & $-4.3029 *$ \\
\hline 14 & -0.0057 & -0.9012 & 0.0435 & 1.1684 & -0.0491 & -1.7045 & -0.7725 & $-4.5290 *$ \\
\hline 15 & -0.0047 & -0.7402 & 0.0388 & 1.0287 & -0.0435 & -1.5079 & -0.8159 & $-4.7170^{*}$ \\
\hline 16 & 0.0157 & $2.4930 *$ & 0.0545 & 1.4245 & -0.0388 & -1.3464 & -0.8547 & $-4.8742 *$ \\
\hline 17 & -0.0028 & -0.4490 & 0.0517 & 1.3328 & -0.0545 & -1.8902 & -0.9092 & $-5.1162 *$ \\
\hline 18 & 0.0009 & 0.1419 & 0.0526 & 1.3383 & -0.0517 & -1.7923 & -0.9609 & $-5.3372 *$ \\
\hline 19 & 0.0032 & 0.5148 & 0.0558 & 1.4029 & -0.0526 & -1.8232 & -1.0135 & $-5.5584 *$ \\
\hline 20 & 0.0005 & 0.0759 & 0.0563 & 1.3975 & -0.0558 & -1.9355 & -1.0693 & $-5.7924 *$ \\
\hline
\end{tabular}

Note: The samples consist of highest $10 \%$ and lowest $10 \%$ of directors' purchases and sales ranked according to the rupee-volume trading. Accordingly, high/low rupee-volume directors' purchases samples include 220 directors' purchases events and sales samples include 94 directors' sales events. The RAR Model is used to measure abnormal returns. Excess AAR/ CAAR are the difference between the AAR/CAAR of the high rupee-volume sample and the low rupee-volume sample. * indicates statistical significance of test statistics at 0.05 level. 
Appendix 2: Excess AAR and Excess CAAR for Directors' Percentage Volume Trading Sub Sample

\begin{tabular}{|c|c|c|c|c|c|c|c|c|}
\hline \multirow[b]{2}{*}{ Day } & \multicolumn{4}{|c|}{ Purchases } & \multicolumn{4}{|c|}{ Sales } \\
\hline & $\begin{array}{c}\text { Excess } \\
\text { AAR }\end{array}$ & $t$-stat & $\begin{array}{l}\text { Excess } \\
\text { CAAR }\end{array}$ & $t$-stat & $\begin{array}{c}\text { Excess } \\
\text { AAR }\end{array}$ & $t$-stat & $\begin{array}{l}\text { Excess } \\
\text { CAAR }\end{array}$ & $t$-stat \\
\hline-20 & 0.0010 & 0.1737 & 0.0010 & 0.1737 & -0.0059 & -0.3893 & -0.0059 & -0.3893 \\
\hline-19 & -0.0023 & -0.3774 & -0.0012 & -0.1441 & -0.0020 & -0.1328 & -0.0079 & -0.3692 \\
\hline-18 & 0.0087 & 1.4461 & 0.0075 & 0.7173 & -0.0113 & -0.7508 & -0.0192 & -0.7349 \\
\hline-17 & -0.0073 & -1.2184 & 0.0001 & 0.0120 & -0.0049 & -0.3237 & -0.0240 & -0.7983 \\
\hline-16 & 0.0016 & 0.2631 & 0.0017 & 0.1283 & -0.0028 & -0.1888 & -0.0269 & -0.7984 \\
\hline-15 & 0.0027 & 0.4435 & 0.0044 & 0.2982 & 0.0032 & 0.2106 & -0.0237 & -0.6429 \\
\hline-14 & -0.0034 & -0.5598 & 0.0010 & 0.0645 & 0.0128 & 0.8497 & -0.0109 & -0.2740 \\
\hline-13 & 0.0005 & 0.0862 & 0.0015 & 0.0908 & 0.0023 & 0.1560 & -0.0086 & -0.2012 \\
\hline-12 & -0.0025 & -0.4131 & -0.0009 & -0.0521 & 0.0015 & 0.0999 & -0.0071 & -0.1564 \\
\hline-11 & 0.0018 & 0.3014 & 0.0009 & 0.0459 & -0.0133 & -0.8822 & -0.0203 & -0.4273 \\
\hline-10 & 0.0073 & 1.2216 & 0.0082 & 0.4121 & 0.0005 & 0.0347 & -0.0198 & -0.3970 \\
\hline-9 & -0.0041 & -0.6806 & 0.0041 & 0.1981 & -0.0153 & -1.0154 & -0.0351 & -0.6732 \\
\hline-8 & 0.0014 & 0.2282 & 0.0055 & 0.2536 & -0.0022 & -0.1483 & -0.0373 & -0.6880 \\
\hline-7 & -0.0038 & -0.6331 & 0.0017 & 0.0752 & -0.0013 & -0.0884 & -0.0387 & -0.6866 \\
\hline-6 & 0.0045 & 0.7502 & 0.0062 & 0.2663 & -0.0060 & -0.3969 & -0.0446 & -0.7658 \\
\hline-5 & -0.0021 & -0.3465 & 0.0041 & 0.1713 & -0.0199 & -1.3253 & -0.0646 & -1.0728 \\
\hline-4 & -0.0013 & -0.2104 & 0.0029 & 0.1151 & -0.0013 & -0.0883 & -0.0659 & -1.0622 \\
\hline-3 & -0.0003 & -0.0493 & 0.0026 & 0.1002 & -0.0162 & -1.0776 & -0.0821 & -1.2862 \\
\hline-2 & -0.0075 & -1.2418 & -0.0049 & -0.1873 & -0.0175 & -1.1624 & -0.0996 & -1.5186 \\
\hline-1 & -0.0040 & -0.6638 & -0.0089 & -0.3310 & -0.0170 & -1.1314 & -0.1166 & -1.7331 \\
\hline 0 & 0.0054 & 0.9022 & -0.0035 & -0.1261 & 0.0021 & 0.1428 & -0.1145 & -1.6602 \\
\hline 1 & -0.0213 & $-3.5384 *$ & -0.0248 & -0.8776 & -0.0832 & $-5.5252 *$ & -0.1976 & $-2.8000^{*}$ \\
\hline 2 & -0.0004 & -0.0671 & -0.0252 & -0.8723 & 0.0002 & 0.0130 & -0.1975 & $-2.7357 *$ \\
\hline 3 & 0.0052 & 0.8581 & -0.0200 & -0.6788 & -0.0010 & -0.0668 & -0.1985 & $-2.6918 *$ \\
\hline 4 & 0.0052 & 0.8575 & -0.0148 & -0.4936 & -0.0013 & -0.0832 & -0.1997 & $-2.6540 *$ \\
\hline 5 & 0.0082 & 1.3680 & -0.0066 & -0.2157 & 0.0045 & 0.3020 & -0.1952 & $-2.5433^{*}$ \\
\hline 6 & -0.0048 & -0.7937 & -0.0114 & -0.3644 & 0.0001 & 0.0079 & -0.1950 & $-2.4942 *$ \\
\hline 7 & 0.0046 & 0.7715 & -0.0067 & -0.2121 & 0.0031 & 0.2047 & -0.1920 & $-2.4106^{*}$ \\
\hline 8 & 0.0066 & 1.0945 & -0.0002 & -0.0051 & 0.0181 & 1.2029 & -0.1739 & $-2.1453^{*}$ \\
\hline 9 & 0.0037 & 0.6119 & 0.0035 & 0.1067 & 0.0104 & 0.6913 & -0.1635 & $-1.9830 *$ \\
\hline 10 & 0.0093 & 1.5451 & 0.0128 & 0.3824 & 0.0125 & 0.8317 & -0.1509 & -1.8014 \\
\hline 11 & -0.0030 & -0.5048 & 0.0098 & 0.2872 & 0.0018 & 0.1189 & -0.1492 & -1.7520 \\
\hline 12 & -0.0025 & -0.4074 & 0.0073 & 0.2119 & -0.0006 & -0.0413 & -0.1498 & -1.7324 \\
\hline 13 & -0.0008 & -0.1376 & 0.0065 & 0.1851 & 0.0002 & 0.0113 & -0.1496 & -1.7048 \\
\hline
\end{tabular}




\begin{tabular}{ccccccccc}
\hline & \multicolumn{9}{c}{ Purchases } & \multicolumn{3}{c}{ Sales } \\
\cline { 2 - 9 } Day & $\begin{array}{c}\text { Excess } \\
\text { AAR }\end{array}$ & $\boldsymbol{t}$-stat & $\begin{array}{c}\text { Excess } \\
\text { CAAR }\end{array}$ & $\boldsymbol{t}$-stat & $\begin{array}{c}\text { Excess } \\
\text { AAR }\end{array}$ & $\boldsymbol{t}$-stat & $\begin{array}{c}\text { Excess } \\
\text { CAAR }\end{array}$ & $\boldsymbol{t}$-stat \\
\hline 14 & -0.0101 & -1.6870 & -0.0037 & -0.1027 & -0.0019 & -0.1270 & -0.1515 & -1.7018 \\
15 & -0.0077 & -1.2749 & -0.0113 & -0.3137 & -0.0059 & -0.3921 & -0.1574 & -1.7433 \\
16 & 0.0096 & 1.5884 & -0.0018 & -0.0483 & -0.0042 & -0.2773 & -0.1616 & -1.7652 \\
17 & 0.0006 & 0.0954 & -0.0012 & -0.0322 & 0.0001 & 0.0077 & -0.1615 & -1.7405 \\
18 & -0.0021 & -0.3441 & -0.0033 & -0.0869 & 0.0005 & 0.0337 & -0.1610 & -1.7127 \\
19 & -0.0038 & -0.6369 & -0.0071 & -0.1865 & 0.0014 & 0.0932 & -0.1596 & -1.6764 \\
20 & 0.0041 & 0.6745 & -0.0030 & -0.0789 & -0.0042 & -0.2781 & -0.1637 & -1.6993 \\
\hline
\end{tabular}

Note: The sample consists of highest $10 \%$ and lowest $10 \%$ directors' purchases and sales ranked according to the percentage-volume trading. Accordingly, high/ low percentage-volume of directors' purchases sample include 220 directors' purchases events and sales samples include 94 directors' sales events. The RAR Model is used to measure normal returns. AAR/ CAAR are the difference between the AAR/CAAR of the high percentage-volume trading sample and the low percentage-volume trading sample. * indicates statistical significance of test statistics at 0.05 level. 